\title{
OPEN Publisher Correction: Frequency and Clinical Associating Factors of Valvular Heart Disease in
}

\section{Min Sun Kim (1), Soo Jin Cho, Sung-Ji Park $\mathbb{D}^{1}$, Sung Won Cho, Soo-Hee Choi, Hye Seung Kim (1), Keumhee Carriere, Eun Kyoung Kim, Sung-A. Chang, Sang-Chol Lee \& Seung Woo Park}

Correction to: Scientific Reports https://doi.org/10.1038/s41598-019-53277-0, published online 14 November 2019

In the original version of this Article, Seung Woo Park was incorrectly listed as the corresponding author. The correct corresponding author for this Article is Sung-Ji Park. Correspondence and requests for materials should be addressed to tyche.park@gmail.com. This error has now been corrected in the HTML and PDF versions of the Article.

\begin{abstract}
(a) Open Access This article is licensed under a Creative Commons Attribution 4.0 International License, which permits use, sharing, adaptation, distribution and reproduction in any medium or format, as long as you give appropriate credit to the original author(s) and the source, provide a link to the Creative Commons license, and indicate if changes were made. The images or other third party material in this article are included in the article's Creative Commons license, unless indicated otherwise in a credit line to the material. If material is not included in the article's Creative Commons license and your intended use is not permitted by statutory regulation or exceeds the permitted use, you will need to obtain permission directly from the copyright holder. To view a copy of this license, visit http://creativecommons.org/licenses/by/4.0/.
\end{abstract}

(C) The Author(s) 2020 